\title{
The Bacterial Pneumonia Characteristics based on Climate and Meteorological Parameters in Indonesia, the Tropical Country: A Preliminary Study
}

\author{
Bramantono $^{1}$, Brian Eka Rachman ${ }^{1 *}$ (iD) Erika Marfiani ${ }^{1}$, Neneng Dewi Kurniati ${ }^{2}$, \\ Muhammad Vitanata Arifijanto ${ }^{1(\mathbb{D})}$, Tuksin Jearanaiwitayakul ${ }^{3}$
}

${ }^{1}$ Division of Infectious Tropics, Department of Internal Medicine, Faculty of Medicine, Universitas Airlangga - Dr. Soetomo General Academic Hospital, Surabaya, Indonesia

${ }^{2}$ Department of Microbiology, Faculty of Medicine, Universitas Airlangga, Surabaya, Indonesia

${ }^{3}$ Department of Microbiology, Faculty of Science, Mahidol University, Bangkok, Thailand.

\section{A R T I C L E I N F O}

\section{Article history:}

Received 15 April 2021

Received in revised form 10 June 2021

Accepted 10 June 2021

Available online 30 June 2021

\section{Keywords:}

Pneumonia,

Bacteria,

Climate change,

Season.

*) Corresponding author:

brian.eka@fk.unair.ac.id

\begin{abstract}
A B S T RA C T
Introduction: As a tropical country, Indonesia has the potential to influence the characteristics of infectious diseases. The purpose of this study was to see how the pattern of pneumonia on various weather components such as rainfall, humidity, and temperature.

Methods: This study was carried by retrospective screening in the infectious ward in one of the tertiary referral hospitals.

Results: A total of 876 cases of pneumonia from eight treatment rooms were included in the study. The highest pneumonia cases occurred in February with 239 (27.2\%) cases followed in April and May with $169(19.2 \%)$ and $159(18.2 \%)$ cases respectively. After microbiological examination, bacterial growth was found in 191 cases. The highest number of bacteria was found in February with $62(32 \%)$, followed by May with $33(17.2 \%)$ and April with $31(16.2 \%)$ samples. Most of the bacterial grown were gram-negative $(94.3 \%)$, dominated by Klebsiella pneumoniae (35\%), followed by Acinetobacter baumanii $17.2 \%$ and Pseudomonas aeruginosa $12 \%$. On the examination of antibiotic sensitivity, it was found that amikacin has a consistently high sensitivity $(90 \%)$ for pneumonia caused by most bacterial causes (Acinetobacter baumanii, Klebsiella pneumoniae, and Escherichia coli).

Conclusion: The study did not show any remarkable bacterial patterns based on weather components such as rainfall, humidity, and temperature during the rainy season. However, increasing the surveillance period will provide a better insight into the bacterial pattern and can compare it in the rainy and dry seasons.
\end{abstract}

\section{Introduction}

Pneumonia is an acute infection or inflammation of the parenchyma or lung tissue, which is currently a health problem. ${ }^{1,2}$ Number of visits to emergency departments with pneumonia as the primary diagnosis in the world is 1.3 million. ${ }^{3}$ Up to $33 \%$ of pneumonia cases are hospitalized. ${ }^{4}$ Pneumonia is still one of the main causes of hospitalization and death in both developed countries ${ }^{5}$ and developing countries. ${ }^{6}$ However, the impact of pneumonia on morbidity and mortality is greater in developing countries. In Indonesia, there are 988 cases per 100,000 hospitalized cases primarily caused by pneumonia. The Case Fatality Rate of pneumonia in adults in Indonesia is up to $11.3 \%$, which is one of the highest in Southeast Asia., ${ }^{2,7}$

Several factors such as agents, hosts, and the environment implicate the increased incidence and mortality of pneumonia. ${ }^{8}$ Climate change, an environmental factor, has become a global concern in the last few decades, causing at least 12.6 million deaths reported by WHO annually., ${ }^{9}$ Changes in average temperature and extreme temperature values, changes in rainfall, and rising sea levels are considered to affect socioeconomic and health. The impact on health can be through undernutrition, mental health, cardiovascular disease, and infectious diseases. Specifically, climate change affects the causes of infectious diseases by changes in host immune response, pathogen activity, and transmission, for example in water-borne disease, ${ }^{11}$ vectorborne diseases, ${ }^{11,12}$ and air-borne disease. ${ }^{11,13}$

Several studies have reported that several climate components such as rainfall, humidity, and temperature affect pneumonia hospitalization. ${ }^{14,15}$ Research in Brazil reports that in winter there is an increased incidence of 
pneumonia, and the lowest incidence occurs in summer. ${ }^{16,17}$ Besides, changes in temperature in weather also affect the incidence of pneumonia hospitalization. ${ }^{18,19}$ Also, cold weather is also associated with an increase in 30-day inhospital mortality by up to $17 \% .^{5}$ However, these studies were reported from various countries with 4 seasons. Although there were studies from 2 season countries that also have the same report, this research was carried out on the African continent. Even though it has the same number of seasons, it is suspected that the characteristics of the host and the environment are different from Asia, especially Indonesia. As far as we are concerned no studies have been conducted to investigate the impact of weather on pneumonia incidence in Asia. Therefore, this study aims to look at the role of climate, especially in the rainy season, with the characteristics of pneumonia being treated in Indonesia, including incidence, etiological patterns, and antibiotic sensitivity patterns.

\section{Methods}

\section{This Data collection}

Our study was carried out by retrospective screening of patients diagnosed with pneumonia in the infectious wards from January to June 2019 at one of the referral center hospitals in East Java, Indonesia, Dr. Soetomo General Academic Hospital Surabaya, Pneumonia is based on history, physical examination, laboratory, and chest X-ray findings. Patients diagnosed with dyspnea other than pneumonia were excluded from the study (Asthma, COPD exacerbation, pulmonary edema, pneumothorax, etc). Sputum examination was performed according to indications and clinical conditions, patients who agreed to do a sputum examination, involved in the research. The patient must be prepared not eating anything for about 1-2 hours before taking sputum. The patient is asked for a sputum examination in the morning. If the patient is difficult to release sputum, the patient will be given steam therapy (nebulizer) in advance to thin the sputum, making it easy to remove. Sputum that comes out is then accommodated in sterile containers for inspection. Inspection in the laboratory takes 2 days to see the growth of bacteria. Meteorological and weather monitoring data were received from the https:// www.bmkg.go.id// website from Indonesia Authorities.

\section{Bacterial identification and antimicrobial susceptibility testing}

After collected, all of the sputum samples were inoculated on blood and MacConkey agar before overnight incubated at $37^{\circ} \mathrm{C}$. On a positive culture result, the identification of bacteria and susceptibility to antibiotics was carried out using the broth microdilution method using a BD Phoenix Automated Microbiology System according to the manufacturer's standard protocols (Phoenix-100; Becton Dickinson Indonesia, Surabaya, Indonesia). Three panels were used for the detection of Gram-negative bacteria (BD Phoenix NMIC / ID Panels for MIC and identification, BD Phoenix NMIC Panels for MIC, and BD Phoenix NID Panels for identification). The broth microdilution method was used in the antimicrobial susceptibility test for the following 9 antibiotics: Trimethoprim-Sulphametoxazole, Ciprofloxacin, Levofloxacin, Ampicillin sulbactam, Imipenem, Meropenem, Amikacin, Ceftriaxone,
Chloramphenicol according to CLSI guidelines. ${ }^{20}$ Data on the number of bacteria, number of cases, antibiotic responses, and climate change are analyzed descriptively. This research has gone through an ethical test from Dr. Soetomo General Academic Hospital Surabaya, East Java, Indonesia.

\section{Results}

\section{Bacterial distribution based on the gram and month of examination}

A total of 876 pneumonia cases from 8 separate wards in the period January-February 2019 were enrolled in this study. The highest pneumonia cases occurred in February with $239(27.2 \%)$ cases followed in April and May, with $169(19.2 \%)$ and $159(18.2 \%)$ cases respectively. From all cases that underwent sputum culture examination, there was bacterial growth in 191 samples. The highest positive culture results were also obtained in February with 62 (32\%), followed by May and April, with 33 (17.2\%) and $31(16.2 \%)$ samples respectively. The bacterial growth was dominated by gram-negative $(94.3 \%)$, with the most bacteria Klebsiella pneumoniae (35\%), followed by Acinetobacter baumaniii and Pseudomonas aeruginosa, 17.2\% and 12\%, respectively. Not only Klebsiella pneumoniae was the largest bacterial contributor in February (which was the highest spike in pneumonia cases during the study period), but also it was the most common bacteria encountered every month. Table 1 showed the distribution of microorganisms.

\section{Case profiles based on weather parameters}

Rainfall intensity shows fluctuation with the highest average intensity occurring in January at $14.19 \mathrm{~mm}$. Interestingly, the decrease in intensity from February to March was followed by a downward trend in pneumonia cases, and its increase during March to April was then followed by an increase in the number of pneumonia cases, although this trend was slightly different from the sharp decrease in rainfall in the month April to June. Just like rainfall, the average highest humidity is also in January at $81.42 \%$ which has a declining trend until June. Although changes in humidity are relatively stable, changes in the number of pneumonia cases show fluctuation. Another case with temperature, the highest was in May at $29.18^{\circ} \mathrm{C}$ and the lowest in June at $28.08^{\circ} \mathrm{C}$. Characteristics of the weather parameters for changes in the number of pneumonia cases can be seen in figure 1 regarding the rainfall profile, figure 2 regarding humidity profile, and figure 3 regarding temperature profile.

\section{Antibiotic sensitivity profile based on most bacterial causes}

The results of the assessment of antibiotic sensitivity profiles, it is known that Amikacin exhibited the highest sensitivity level above $90 \%$ in the pneumonia case caused by A. Baumaannii, Klebsiella pneumoniae, or Escherichia coli. Some antibiotics that are mostly used in pneumonialike Levofloxacin have a low antibiotic sensitivity with lower lesser than $76.56 \%$ in all tested bacteria. Particularly, the antibiotic sensitivity of LEV was lower than $12.50 \%$ against Escherichia coli. Likewise, Ceftriaxone showed the antibiotic sensitivity no more than $59.38 \%$ in common causative bacterias in this study. Table 2 shows the comparison of antibiotic sensitivity to the causative bacteria. 
Table 1. Distribution Profile of Microorganisms

\begin{tabular}{|c|c|c|c|c|c|c|c|c|}
\hline Bacteria & Microorganisms & $\begin{array}{c}\text { January } \\
(\mathrm{n} \%)\end{array}$ & $\begin{array}{c}\text { February } \\
(\mathrm{n} \%)\end{array}$ & $\begin{array}{c}\text { March } \\
(\mathrm{n} \%)\end{array}$ & $\begin{array}{l}\text { April } \\
(\mathrm{n} \%) \\
\end{array}$ & $\begin{array}{l}\text { May } \\
(\mathrm{n} \%)\end{array}$ & $\begin{array}{l}\text { June } \\
(\mathrm{n} \%)\end{array}$ & Total \\
\hline \multirow{2}{*}{$\begin{array}{l}\text { Gram Positive } \\
\text { Bacteria }\end{array}$} & Staphylococcus aureus & $3(1.5)$ & $4(2)$ & $1(0.5)$ & $1(0.5)$ & & $1(0.5)$ & $10(5.2)$ \\
\hline & Staphylococcus lentus & & $1(0.5)$ & & & & & $1(0.5)$ \\
\hline \multirow{14}{*}{$\begin{array}{l}\text { Gram Negative } \\
\text { Bacteria }\end{array}$} & Klebsiella pneumoniae & $6(3.1)$ & $33(17.2)$ & $5(2.6)$ & $6(3.1)$ & $12(6.2)$ & $5(2.6)$ & $67(35)$ \\
\hline & $\begin{array}{l}\text { Acinetobacter baumannii/ } \\
\text { calcoaceticus complex }\end{array}$ & $1(0.5)$ & $5(2.6)$ & $9(4.7)$ & $5(2.6)$ & $6(3.1)$ & $7(3.6)$ & $33(17.2)$ \\
\hline & Pseudomonas aeruginosa & & $7(3.6)$ & $1(0.5)$ & $3(1.5)$ & $5(2.6)$ & $7(3.6)$ & $23(12)$ \\
\hline & Escherichia coli & $2(1)$ & $3(1.5)$ & $3(1.5)$ & $5(2.6)$ & $3(1.5)$ & & $16(8.3)$ \\
\hline & $\begin{array}{l}\text { The organism is not } \\
\text { detected }\end{array}$ & & $2(1)$ & $1(0.5)$ & $4(2)$ & $4(2)$ & & $11(5.7)$ \\
\hline & Enterobacter cloacae & & $2(1)$ & $1(0.5)$ & $2(1)$ & $2(1)$ & $3(1.5)$ & $10(5.2)$ \\
\hline & Aeromonas caviae & $1(0.5)$ & $1(0.5)$ & $1(0.5)$ & $3(1.5)$ & & & $6(3.1)$ \\
\hline & $\begin{array}{l}\text { Stenotrophomonas } \\
\text { maltophilia }\end{array}$ & $2(1)$ & & $1(0.5)$ & & & & $3(1.5)$ \\
\hline & Klebsiella oxytoca & & $2(1)$ & & & & & $2(1)$ \\
\hline & Klebsiella ozaenae & & & & $1(0.5)$ & $1(0.5)$ & & $2(1)$ \\
\hline & Kluyvera ascorbata & & $1(0.5)$ & & $1(0.5)$ & & & $2(1)$ \\
\hline & Providencia stuartii & & $1(0.5)$ & $1(0.5)$ & & & & $2(1)$ \\
\hline & Serratia marcescens & & & $2(1)$ & & & & $2(1)$ \\
\hline & Sphingomonas paucimbilis & & & $1(0.5)$ & & & & $1(0.5)$ \\
\hline Total & & $\begin{array}{c}15 \\
(7.8)\end{array}$ & $\begin{array}{c}62 \\
(32)\end{array}$ & $\begin{array}{c}27 \\
(14.1)\end{array}$ & $\begin{array}{c}31 \\
(16.2)\end{array}$ & $\begin{array}{c}33 \\
(17.2)\end{array}$ & $\begin{array}{c}23 \\
(12)\end{array}$ & $\begin{array}{c}191 \\
(100)\end{array}$ \\
\hline
\end{tabular}

Table 2. Antibiotic Sensitivity Profile

\begin{tabular}{lccccccccc}
\hline & \multicolumn{1}{c}{ Sensitivity (\%) } \\
\cline { 2 - 10 } \multicolumn{1}{c}{ Bacteria } & SAM & CIP & LEV & IMP & MEM & CM & AK & CRO & SXT \\
\hline A. baumannii & 71.43 & 46.43 & 57.14 & 82.14 & 81.48 & 50.00 & 92.86 & 39.29 & 82.14 \\
\hline Klebsiella pneumoniae & 54.69 & 68.75 & 76.56 & 71.88 & 73.44 & 76.56 & 93.75 & 59.38 & 68.75 \\
\hline Escherichia coli & 17.50 & 12.50 & 12.50 & 81.25 & 81.25 & 56.25 & $100 \%$ & 18.75 & 37.50 \\
\hline
\end{tabular}

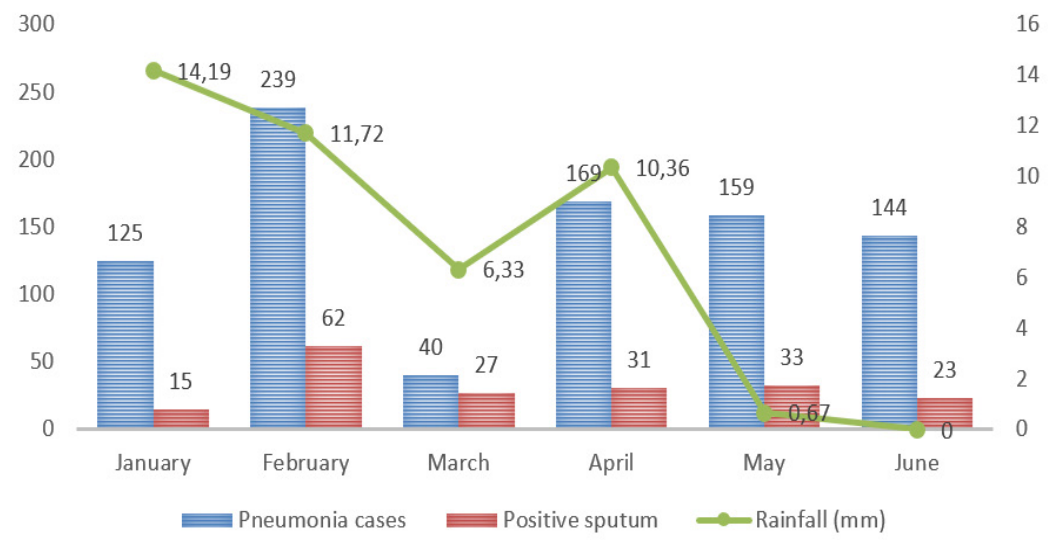

Figure 1. Pneumonia Cases Based on Rainfall Profile in Rainy Season 


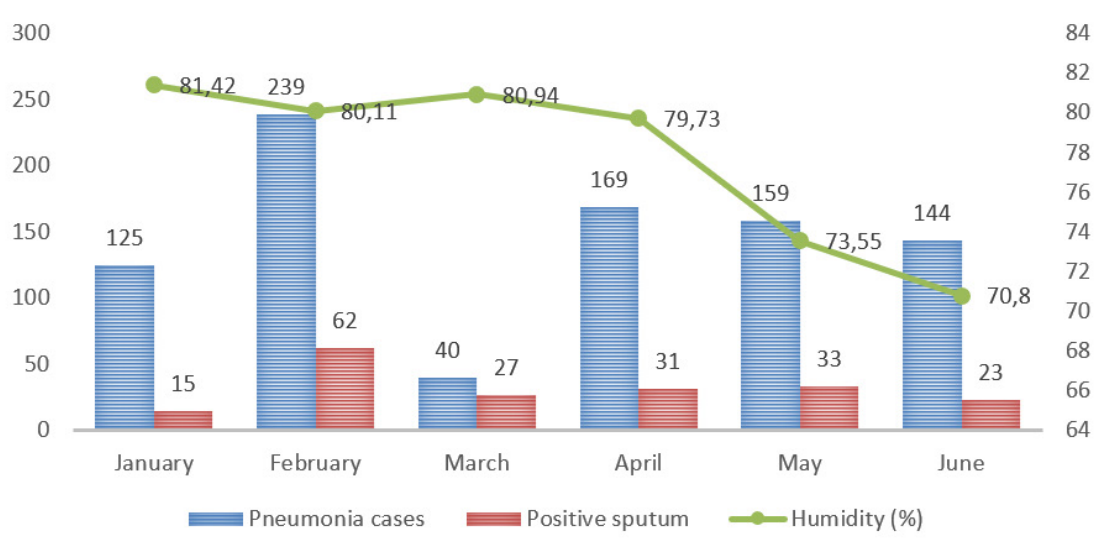

Figure 2. Pneumonia Cases Based on Humidity Profile in Rainy Season

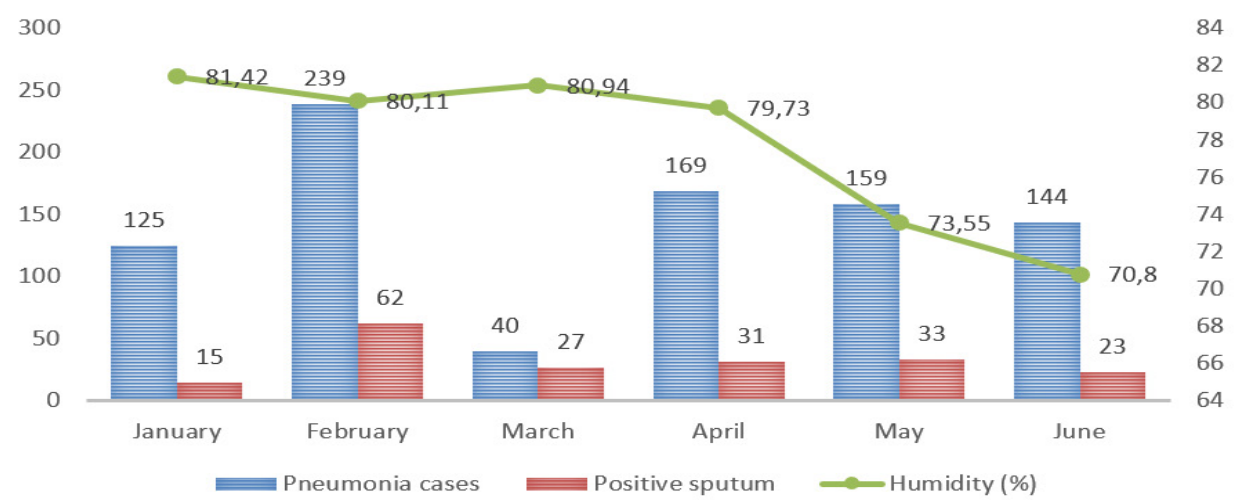

Figure 3. Pneumonia Cases Based on Temperature Profile in Rainy Season

\section{Discussion}

Age Indonesia is known as one of the tropical countries in Asia, so it has two seasons. On the other hand, Indonesia as a tropical and developing country has a higher prevalence of infectious diseases than other countries. One of the most common infections that brings a person into hospitalization is a respiratory tract infection, one of which is pneumonia. The incidence of pneumonia itself is a complex matter consisting of various underlying factors, such as agent, host, and environmental factors. ${ }^{8}$

Several studies from various countries with four seasons have been reported an increased incidence of pneumonia $^{16,17}$ and hospitality ${ }^{6,14}$ in winter-related to temperature differences. However, these temperature differences were not followed by an increased incidence of pneumonia as described in this study. Though, there is a difference in the mean temperature between the summer and the rainy season in a tropical country like Indonesia, there is no extreme variability of temperature in the rainy season itself (range 28.08 to $29.18^{\circ} \mathrm{C}$ ) (Meteorological,
Climatological, and Geophysical Reports, https:/www. bmkg.go.id).

Likewise, with rainfall in Turkey, it is reported that its effect of temperature differences associated with an increased incidence of pneumonia. ${ }^{17}$ However, what is interesting in this study, although the pattern of pneumonia incidence is in line with rainfall in February to April, this is not the case in other months. This may imply that weather is not a determining factor for pneumonia incidence requiring hospitalization. This can be related to the behavior of the community to postpone visits to the hospital when the rainfall intensity is high. Often health priorities are placed at such a number, so they are more focused on the impact of high rainfall such as floods (unpublished data). This is supported by a systematic review which states that there is a complex relationship between pneumonia incidence, pneumonia hospitalization, and the variability of weather components. ${ }^{21}$

Another case with other studies that reported the incidence of pneumonia ${ }^{22}$ even pneumonia death ${ }^{23}$ increases due to differences in humidity. Likewise in the form 
of a model, in Felix et al's study, where humidity and temperature influenced pneumonia, but not in this study, it could be because in this study the average temperature was higher $\left(28.08-29.18^{\circ} \mathrm{C}\right.$ vs $\left.23.3-29.3^{\circ} \mathrm{C}\right)$, and higher humidity (70.8 - 81.42 vs $52.3-56.4)$.

In this study, during the rainy season itself, the weather components such as temperature, humidity, and rainfall did not change following an increase in the incidence of pneumonia and an increase in bacterial culture results in February. This is similar to research in Thailand which states that several factors have a stronger influence than weather components such as rainfall, temperature, and humidity, such as pollution factors such as PM10 levels. ${ }^{15}$ Apart from that several host factors such as nutritional status, ${ }^{24,25}$ smoke, ${ }^{24,25,26}$ comorbid, ${ }^{24}$ poor dental hygiene, ${ }^{24,25}$ previous history of pneumonia, ${ }^{25,26}$ history of taking immunosuppressants, ${ }^{25}$ endogenous rhythm ${ }^{27}$ may be more influential than environmental factors. Another study also reported that although mortality increased in winter, it was not significant in the multivariate analysis. ${ }^{5}$

The best management of infectious diseases is the eradication of the microorganisms that cause them. From various microorganisms that cause pneumonia, ${ }^{28,29}$ Bacteria are the most common cause of hospitalization, poor morbidity, and mortality. ${ }^{30}$ The most ideal condition is to isolate microorganisms to determine the exact causative agents that mediate pneumonia, but the 2019 American Thoracic Society (ATS) only recommends sputum culture examinations in conditions of severe pneumonia and/or with the risk of being infected with Pseudomonas aeruginosa and MRSA such as a history of being hospitalized or getting parenteral antibiotics in the last 90 days. ${ }^{31}$ The purpose of bacterial isolation is in addition to identifying resistant bacteria, narrowing antibiotic therapy, adjusting failed therapies. ${ }^{31}$ Although the most common bacteriacaused- pneumonia are Streptococcus pneumonia. ${ }^{28,16,32}$ and Haemophilus influenzae are supported by a systematic review. ${ }^{33}$ In this study, the most common bacteria found was Klebsiella pneumoniae. This is consistent with research in various regions in Indonesia, including Padang, ${ }^{34} \mathrm{Bali},{ }^{35}$ and Lampung. ${ }^{36}$ The difference in the characteristics of the main causative bacteria is answered by a report from a systematic review where although Streptococcus pneumonia is the most common cause, its prevalence varies from 4 to $24 \%$. Uniquely, this prevalence is getting smaller as a country gets closer to the equator. ${ }^{37}$ Another interesting thing is that although geographically and weather have different characters, it turns out that the time factor is also related. The result shows that the cause of pneumonia varies at the study site even in the same hospital as the study site now, $S$. pneumoniae was the most prevalent pathogen causing pneumonia in Dr. Soetomo General Academic Hospital on 2014-2016. ${ }^{38}$ The shift in the antibiogram could be due to the possibility of expanding the use of the pneumococcal vaccine and improving the referral system.

The increasing number of antibiotic use in infectious diseases will be followed by an increase in the number of antibiotic resistance. To minimize this, a guideline of an antibiotic sensitivity pattern is needed. The ATS issues guidelines for the use of antibiotics using a combination of $\beta$-lactam and macrolide or respiratory fluoroquinolone in non-severe cases and a combination of $\beta$-lactam and macrolide or $\beta$-lactam and respiratory fluoroquinolone in severe cases. ${ }^{31}$ What's interesting about this study, it turns out that the sensitivity to respiratory fluoroquinolone is only $12.5-76.56 \%$. While the sensitivity of ceftriaxone was only $18.75-59.38 \%$. This could be related to the tiered referral system in effect in the last six years. The rules for conducting a tiered referral in Indonesia have been carried out since Indonesia implemented the national health insurance in $2014 .{ }^{39}$ So that the low sensitivity of bacteria to these antibiotics can be caused by the frequency of patients receiving treatment from these antibiotics in the previous hospital. Although this study does not directly relate the influence of weather with the characteristics of antibiotic sensitivity, in other studies it is reported that weather variations has an effect on antibiotic characteristics, where AMR rates are higher in weather with lower temperatures than others. This can be caused by changes in the dynamics of antibiotic used which tend to increase inline with the increase in cases. ${ }^{40}$

Although antibiotic guidelines for pneumonia have been issued by the ATS, several studies report a cluster of pathogens mainly due to the increased prevalence of MRSA and Pseudomonas not responding to standard antibiotic regimens. ${ }^{41,42}$ Pseudomonas aeruginosa is a versatile Gramnegative bacterium that is the top three causative agent of nosocomial pneumonia which often causes prolonged hospitalization, increasing morbidity and mortality by up to $72 \% .^{41,43,41}$ Even the ATS itself gives special attention by making special treatment regimens in groups at risk of being infected with Pseudomonas aeruginosa. In this study, isolation of Pseudomonas aeruginosa was obtained in $23(12 \%)$ samples. This amount in the present study was lower than the study conducted by Zorana which reported the prevalence of Pseudomonas aeruginosa of $23.5 \% .^{44}$ Other results were found in a Prospective cohort study in the central ICU of Kragujevac Clinical Center, Serbia that Gram-negative agents were isolated in 95.2\%. Generally, the most common pathogens were Acinetobacter spp. and Pseudomonas aeruginosa, accounting for over $60 \%$ of isolates. ${ }^{44}$ A study in Jakarta, Indonesia found that Basil gram-negative aerobes $(79.5 \%)$ were the most dominant causative microorganisms, Pseudomonas $s p .{ }^{45}$ In that study the sample was taken in the intensive care room, while in the study it was taken in the usual care room.

The weakness of this study is that this research is only done in the rainy season, it must be carried out until the dry season in the last few years to be able to see the pattern comprehensively. Also, this study discusses pneumonia caused by bacteria. Future studies are expected to involve the virus so that differences and specific treatments can be found to cause pneumonia in terms of bacteria and viruses.

\section{Conclusion}

In the rainy season, patterns of changes in weather components such as rainfall, humidity, and temperature are not followed by an increase in cases of pneumonia. Besides, with the finding of low antibiotic sensitivity recommended by the International guidelines, local regulations, and strategies needed to be periodically updated. 


\section{Acknowledgement}

We would like to thank Dr. Soetomo General Academic Hospital for facilitating the continuity of the research. We also thank the medical personnel who took care of the patients and were involved in the management of the research isolates.

\section{Conflict of Interest}

The author stated there is no conflict of interest

\section{References}

1. Parul Pahal; Sandeep Sharma. Typical Bacterial Pneumonia. In: StatPearls. Treasure Island: StatPearls Publishing; 2020.

2. Azmi S, Aljunid SM, Maimaiti N, Wibowo B, Komaryani K, Roberts C. Assessing the burden of pneumonia using administrative data from Malaysia, Indonesia, and the Philippines. Int $\mathrm{J}$ Infect Dis. 2016;49:87-93.

3. CDC. Pneumonia [Internet]. 2019 [cited 2020 Aug 26]. Available from: https:/www.cdc.gov/nchs/fastats/pneumonia.htm

4. Iroezindu MO, Isiguzo GC, Chima EI, Mbata GC, Onyedibe KI, Onyedum CC, et al. Predictors of in-hospital mortality and length of stay in community-acquired pneumonia: A 5-year multi-center case control study of adults in a developing country. Trans R Soc Trop Med Hyg. 2016;110(8):445-55.

5. Callaly E, Mikulich O, Silke B. Increased winter mortality: The effect of season, temperature and deprivation in the acutely ill medical patient. Eur J Intern Med. 2013;24(6):546-51.

6. Benincà E, Van Boven M, Hagenaars T, Van Der Hoek W. Spacetime analysis of pneumonia hospitalisations in the Netherlands. PLoS One. 2017;12(7):1-14

7. Wahab A, Choiriyyah I, Wilopo SA. Determining the cause of death: Mortality surveillance using verbal autopsy in Indonesia. Am J Trop Med Hyg. 2017;97(5):1461-8.

8. Centers for Disease Control and Prevention (CDC). Principles of Epidemiology in Public Health Practice - An Introduction to Applied Epidemiology and Biostatistics. Third. Third Edition. Atlanta: CDC; 2012.

9. World Health Organization (WHO). An estimated 12.6 million deaths each year are attributable to unhealthy environments [Internet]. [cited 2020 Aug 13]. Available from: https://www.who.int/en/news-room/ detail/15-03-2016-an-estimated-12-6-million-deaths-each-year-areattributable-to-unhealthy-environments

10. Prüss-Ustün A, Wolf J, Corvalán C, Neville T, Bos R, Neira M. Diseases due to unhealthy environments: An updated estimate of the global burden of disease attributable to environmental determinants of health. J Public Heal (United Kingdom). 2017;39(3):464-75.

11. Chowdhury FR, Ibrahim QSU, Bari M.S, Alam MMJ, Dunachie SJ, Rodriguez-Morales AJ et al. The association between temperature, rainfall and humidity with common climate sensitive infectious diseases in Bangladesh. PLoS One. 2018;13(6):e0199579.

12. Tian HY, Bi P, Cazelles B, Zhou S, Huang SQ, Yang J, et al. How environmental conditions impact mosquito ecology and Japanese encephalitis: An eco-epidemiological approach. Environ Int. 2015 Jun 1;79:17-24.

13. Rao H-X, Zhang X, Zhao L, Yu J, Ren W, Zhang X-L, et al. Spatial transmission and meteorological determinants of tuberculosis incidence in Qinghai Province, China: a spatial clustering panel analysis. Infect Dis Poverty. 2016;5(1):45.

14. Liu Y, Kan H, Xu J, Rogers D, Peng L, Ye X, et al. Temporal relationship between hospital admissions for pneumonia and weather conditions in Shanghai, China: A time-series analysis. BMJ Open. 2014;4(7).

15. Ruchiraset A, Tantrakarnapa K. Time series modeling of pneumonia admissions and its association with air pollution and climate variables in Chiang Mai Province, Thailand. Environ Sci Pollut Res. 2018;25(33):33277-85.

16. Herrera-Lara S, Fernández-Fabrellas E, Cervera-Juan Á, BlanquerOlivas R. Do Seasonal Changes and Climate Influence the Etiology of Community Acquired Pneumonia? Arch Bronconeumol. 2013;49(4):140-5.

17. Tasci SS, Kavalci C, Kayipmaz AE. Relationship of Meteorological and Air Pollution Parameters with Pneumonia in Elderly Patients. Emerg Med Int. 2018;2018:1-9.

18. Sohn S, Cho W, Kim JA, Altaluoni A, Hong K, Chul Chun B.
"Pneumonia weather": Short-term Effects of Meteorological Factors on Emergency Room Visits Due to Pneumonia in Seoul, Korea. J Prev Med Public Heal. 2019;52(2):82-91.

19. Qiu H, Sun S, Tang R, Chan KP, Tian L. Pneumonia Hospitalization Risk in the Elderly Attributable to Cold and Hot Temperatures in Hong Kong, China. Am J Epidemiol. 2016;184(8):570-8.

20. PA W. CLSI Performance Standards for Antimicrobial Susceptibility Testing CLSI Supplement M100. 29th ed. Clinical and Laboratory Standards Institute (CLSI); 2019.

21. Murdoch KM, Mitra B, Lambert S, Erbas B. What is the seasonal distribution of community acquired pneumonia over time? A systematic review. Australas Emerg Nurs J. 2014;17(1):30-42.

22. Su Q, Liu H, Yuan X, Xiao Y, Zhang X, Sun R, et al. The Interaction Effects of Temperature and Humidity on Emergency Room Visits for Respiratory Diseases in Beijing, China. Cell Biochem Biophys. 2014;70(2):1377-84

23. Davis RE, Dougherty E, McArthur C, Huang QS, Baker MG. Cold, dry air is associated with influenza and pneumonia mortality in Auckland, New Zealand. Influenza Other Respi Viruses. 2016;10(4):310-3.

24. Torres A, Peetermans WE, Viegi G, Blasi F. Risk factors for community-acquired pneumonia in adults in Europe: A literature review. Thorax. 2013;68(11):1057-65.

25. Almirall J, Serra-Prat M, Bolíbar I, Balasso V. Risk Factors for Community-Acquired Pneumonia in Adults: A Systematic Review of Observational Studies. Respiration. 2017;94(3):299-311.

26. Muthumbi E, Lowe BS, Muyodi C, Getambu E, Gleeson F, Scott JAG. Risk factors for community-acquired pneumonia among adults in Kenya: a case-control study. Pneumonia. 2017;9(1):1-9.

27. Dowell SF, Whitney CG, Wright C, Rose CE, Schuchatt A. Seasonal patterns of invasive pneumococcal disease. Emerg Infect Dis. 2003;9(5):573-9.

28. El-Solh AA, Sikka P, Ramadan F, Davies J. Etiology of severe pneumonia in the very elderly. Am J Respir Crit Care Med. 2001;16:645-651.

29. Asghar AH, Ashshi AM, Azhar EI, Bukhari SZ, Zafar TA, Momenah AM. Profile of bacterial pneumonia during Hajj. Indian J Med Res. 2011;133(5):510-3.

30. Saud Bin Abdul Sattar; Sandeep Sharma. Bacterial Pneumonia. Treasure Island (FL): StatPearls Publishing; 2020.

31. Metlay JP, Waterer GW, Long AC, Anzueto A, Brozek J, Crothers $\mathrm{K}$, et al. Diagnosis and treatment of adults with community-acquired pneumonia. Am J Respir Crit Care Med. 2019;200(7):E45-67.

32. Sutrisno E, Humardewayanti R, Bayupurnama P. Impact of irrational antibiotic therapy to hospital cost of care of pneumonia in patients in Dr. Sardjito Hospital. Acta Interna J Intern Med. 2013;3(2):67-71.

33. Goyet S, Vlieghe E, Kumar V, Newell S, Moore CE, Bousfield R, et al. Etiologies and resistance profiles of bacterial community-acquired pneumonia in cambodian and neighboring countries' health care settings: A systematic review (1995 to 2012). PLoS One. 2014;9(3).

34. Lubis VA, Katar Y, Bahar E. Identifikasi Bakteri Infeksi Saluran Pernafasan Bawah Non Tuberkulosis (Non TB) dan Pola Resistensinya pada Penderita Diabetes Melitus di RSUP M. Djamil. J Kesehat Andalas. 2016;5(3).

35. Budayanti NS, Suryawan K, Iswari IS, Sukrama DM. The Quality of Sputum Specimens as a Predictor of Isolated Bacteria From Patients With Lower Respiratory Tract Infections at a Tertiary Referral. Front Med. 2019;6:1-6.

36. Alfarizi ME. Pola Mikroorganisme Penyebab Pneumonia dan Sensitivitasnya terhadap antibiotik di masyarakat bandar lampung. Universitas Lampung; 2017.

37. Peto L, Nadjm B, Horby P, Thi T, Ngan D, Doorn R Van, et al. The bacterial aetiology of adult community-acquired pneumonia in Asia : a systematic review. Trans R Soc Trop Med Hyg. 2014;(April):326-37.

38. Purba AK, Ascobat P, Muchtar A, Wulandari L, Rosyid AN, Purwono $\mathrm{PB}$, et al. Multidrug-resistant infections among hospitalized adults with community-acquired pneumonia in an Indonesian tertiary referral hospital. Infect Drug Resist. 2019;12:3663-75.

39. Ratnasari D. Analisis Pelaksanaan Sistem Rujukan Berjenjang Bagi Peserta JKN di Puskesmas X Kota Surabaya. J Adm Kesehat Indones. 2018;5(2):145.

40. Martinez P, Cepeda, Jovanoska, Bramer WM, Schoufour J, Glisic $\mathrm{M}$, et al. Seasonality of antimicrobial resistance rates in respiratory bacteria: A systematic review and meta-analysis. PLoS One. 2019;14(8):1-14.

41. Micek ST, Wunderink RG, Kollef MH, Chen C, Rello J, Chastre J, et al. An international multicenter retrospective study of Pseudomonas aeruginosa nosocomial pneumonia: Impact of multidrug resistance. 
Crit Care. 2015;19(1):219.

42. Kollef MH, Shorr A, Tabak YP, Gupta V, Liu LZ, Johannes RS. Epidemiology and outcomes of health-care-associated pneumonia: Results from a large US database of culture-positive pneumonia. Chest. 2005;128(6):3854-62.

43. Ramos GP, Rocha JL, Tuon FF. Seasonal humidity may influence Pseudomonas aeruginosa hospital-acquired infection rates. Int $\mathrm{J}$ Infect Dis. 2013;17(9):e757-61.

44. Djordjevic ZM, Folic MM, Jankovic SM. Distribution and antibiotic susceptibility of pathogens isolated from adults with hospitalacquired and ventilator-associated pneumonia in intensive care unit. J Infect Public Health. 2017;10(6):740-4.

45. Widyaningsih R, Buntaran L. Pola Kuman Penyebab Ventilator Associated Pneumonia(VAP) dan Sensitivitas Terhadap Antibiotik di RSAB Harapan Kita. Sari Pediatr. 2016;13(6):384. 